\title{
What do College Learners Think of Synchronous Learning?
}

\author{
Gentjana Taraj \\ "Aleksander Moisiu" University, Durres, Albania \\ https://orcid.org/0000-0001-9865-3058
}

\begin{abstract}
Advancements in educational technology and improvements in the internet's connectivity has increased the interest of universities in elearning worldwide. Unlike many institutions around the world, the traditional form of teaching in Albania before the Covid-19 pandemic was face-to-face where both lectures and seminars were attended physically in the classroom. However, the Covid-19 pandemic imposed on them the necessity to move from auditoriums to e-learning immediately without any preparation. This paper aims to investigate the Albanian learners' attitudes and perceptions of synchronous e-learning during the second semester of the 2019 - 2020 academic year. A survey consisting of 15 questions was distributed to a total of 168 undergraduate and graduate learners in 2 public universities in Albania. Results from the study showed that the learners preferred face-to-face learning over synchronous learning. The lack of motivation, low level of interaction with their instructors and peers, and the feeling of isolation were their main concerns. Meanwhile, the learners appreciated the fact that elearning helped them to improve their computer and internet skills. It is also less expensive and more comfortable than the traditional mode of teaching and learning.
\end{abstract}

Keywords: synchronous learning; face to face learning; motivation; interaction; Covid-19 pandemic

\section{Introduction}

The digital arena has made it possible for anyone who has got the right device and internet access to easily retrieve any kind of information related to education, making it a great environment for e-learning services (Cojocariu et al., 2014). This has contributed to distance learning becoming a trend which has been widely adapted by academic institutions everywhere (Allen \& Seaman, 2013; Kentnor, 2015). This increase in popularity has led to the writing of many research papers that analyse not only the different types of distance learning (Morris, 2014; Valverde-Berrocoso et al., 2020) but also the pitfalls and challenges that are necessary to be addressed by administrators and instructors for the effective 
adaptation of online programs (Lee, 2008; Bhuasiri et al., 2012; Cheawjindakarn et al., 2012; Porter et al., 2014; Alammary et al., 2014).

Unlike universities in developed countries, for Albanian IHEs (Institutions of Higher Education), e-learning is a completely new experience. In the last few decades, Albania has been going through major changes in many areas of its social life. One of these areas is education. It has been affected by many forms of transformation that have led to improvements and advancements in the teaching and learning process. Some of these changes concern the digitalization of the teaching process such as the use of smartboards, electronic class registers, the internet, video projectors, electronic libraries and so on. However, the most distinct experience was the shift from face-to-face instructions to online classes which did not come as a natural process but as a necessity due to the pandemic situation that has affected the whole world.

The present study aims to evaluate the Albanian learners' attitude towards online learning during Covid-19 pandemic. An online survey was administered in late October 2020 exploring the learners' perceptions of their experience. The factors that affect these attitudes, such as the internet and computer literacy, prior experiences with online platforms and social interactions, were considered.

\section{Literature Review}

\subsection{Synchronous E-Learning Defined}

Synchronous learning is defined as "live, real time (and usually scheduled), facilitated instruction and learn-ing-oriented interaction" (Murray, 2007, p.1). It is also known by other names such as virtual classrooms, web conferencing, webinars etc. In a synchronous learning environment, the learners and instructors meet online at and for a predetermined time. It allows the instructors and learners to interact in real time, which creates room for instant feedback. Although e-learning has been the focus of research for a long time, its application during the Covid-19 pandemic has been unprecedented since for many countries the shift from face-to-face to the e-learning format occurred overnight. This explains the inconsistency in the results reported by studies on synchronous learning where its application was gradual and the findings coming from studies conducted on synchronous learning in the context of the pandemic. In this review, we will analyse e-learning effectiveness by considering the previous research and e-learning experience during the pandemic in IHEs that had no prior experience with online programs.

\subsection{Synchronous Learning Before the Covid-19 Pandemic}

Synchronous e-learning offers many important advantages which makes it preferable in an educational environment. According to Murray (2007), synchronous e-learning connects users together no matter how far apart they live in relation to the university setting. It does not require physical participation which reduces the learners' travel expenses and allows them to have a job (Yilmaz, 2019). Comparing asynchronous to synchronous e-learning, Hrastinski (2008) concluded that synchronous e-learning increases the learners' motivation and psychological arousal. The same positive results were found in Park and Bonk's study (2007), where the learners showed satisfaction with the immediate feedback, the instructors' support and the meaningful interactions. Live meetings 
in small groups created meaningful and supportive collaborations which helped the learners take on an active role.

Computer technology is highly related to the success of the e-learning environment ( $\mathrm{Li} \&$ Lee, 2016). For example, Yuzer et al. (2009) found that computer literacy reduced the learners' level of anxiety through the use of visual support (pictures, graphs, tables etc) which helped them with the comprehension of the reading material. Also, the learners' participation was increased in virtual classes as each learner had the same amount of time to answer the instructors' questions. Another study by Zabadi and Al-alai, (2016) investigated the relationship between the learners' gender, technology usage and technology skills variables and the learners' attitude towards e-learning. The study showed that each of them had a significant effect on the learners' positive attitude.

Efforts to study the strengths and weaknesses in the adaptation of e-learning programs and the role of institutions in this process are found in many studies (Abel, 2015). Porter et al. (2014) described blended learning as a process that goes through three stages: awareness, adaptation, and implementation. They concluded that the advocacy among faculty members, university administrators and personnel is the key to success in this process. Sharing the same view, Betts (1998) considers the faculty to be an essential element in the successful implementation of e-learning programs. She identified the crucial factors positively related to this process: the faculty experience of education, the previous knowledge and experience with distance learning, administration support, training the teaching staff with a focus on distance education and above all, the faculty interest in developing a distance-education policy (Phelps \& Vlachopoulos, 2019; Seifert, 2019).

\subsection{Synchronous Learning During the Covid-19 Pandemic}

The e-learning application during Covid-19 has not been without problems (Chen et al., 2020; Jan, 2020; Shukri et al., 2020; Yang et al., 2020). A lack of digitalization and unfamiliarity with online approaches has reduced the effectiveness of elearning in a number of ways (Muthuprasad, 2021; Karayaka et al., 2020). For example, the learners' and instructors' computer skills where they were below the satisfactory level were shown to have a negative impact on their motivation (Aytac, 2020). In addition, Ferri et al. (2020) found that a poor internet connection and a lack of electronic devices challenged e-learning as a practice across multiple countries as it related to the level of income within said countries.

Investigating the Romanian learners' perception of e-learning, Coman et al. (2020) reported a negative attitude which was influenced by an impaired interaction between the teacher-student and student-student, poor technical skills and a teacher-inappropriate teaching style. A lack of motivation, increased anxiety and distractions were highlighted as the barriers for American learners (Gillis \& Krull, 2020). Other reasons for preferring face to face learning over synchronous learning were the learners' poor management of the study pace and minimal social interactions (Zhou et al., 2020). The same difficulties were reported by Greek learners (Raikou et al., 2020). 
However, despite the challenges reported in the application of e-learning during the Covid-19 pandemic, it has been considered an opportunity to learn from previous experiences and to develop new pedagogical approaches and institutional policies to take the education system to a higher level (Ramola, 2021; Toquero, 2020). Studies carried out around the world conclude that policy level interventions are crucial to improve the e-learning situation. It has been suggested that governments should intervene to secure an internet connection, to provide free digital devices and to reduce the cost of computers whereas institutions should use proper virtual learning environments, train their instructors and learners on how to use the online platforms and provide tools for an effective learning experience, in addition to adapting the pedagogical approaches to the new learning environment by fostering more interactive and innovative teaching techniques. These are some of the lessons that have been learnt during this process (Pellegrini, 2020; Brereton, 2021; Ferri et al., 2020; Pokhrel \& Chhetri, 2021).

\section{Research Method}

\subsection{Context and Participants}

The participants in this study were undergraduate and graduate learners $(\mathrm{N}=168)$ pursuing a Bachelor or Master's degree in two state universities in Albania. The majority of the participants were female $(\mathrm{N}=149)$ and most of them were undergraduate learners $(\mathrm{N}=115)$. They were enrolled in synchronous courses during the second semester of the 2019 - 2020 academic year in the field of humanities and sciences. Table 1 presents the profile of the participants who responded to the survey.

Table 1. Demographic profile of the participants

\begin{tabular}{|l|l|l|}
\hline Category & Nr. of participants & Percentage \\
\hline Gender & 149 & 88.7 \\
\hline Female & 19 & 11.3 \\
\hline Male & 115 & 68.5 \\
\hline Programs of Study & 31.5 \\
\hline Bachelor's & 53 & 65.5 \\
\hline Master's & 110 & 34.5 \\
\hline Region & 58 & \\
\hline Urban area & $18-27$ years old \\
\hline Rural area &
\end{tabular}

\subsection{Instrument}

The researcher has opted to use a survey as the data collection instrument which covers 15 questions regarding the students' experience of virtual classrooms. The learners were invited to participate in the survey via email which contained the link to the survey. They were informed that their participation was voluntary and anonymous. A copy of the survey can be found in Appendix A of this paper. In the survey, the learners were asked to respond to questions using a Likert Scale ranging from 1 (Strongly Disagree) to 5 (Strongly Agree). In addition, there were questions which required a Yes - No answer. The online survey was administered using SurveyMonkey. The data was analysed using the Statistical Package for Social Science (SPSS) version 20. The descriptive statistics of the responses to the 
survey are presented in appropriate tables with the percentages and frequencies of the responses displayed.

\section{Descriptive Results}

The research method used a descriptive quantitative survey. The purpose was to explore the perception of both graduate and undergraduate learners of synchronous learning. The learning experience during the Covid-19 pandemic has made it clear that technology is not the only problem faced by Albanian learners. The present survey explores two main areas of interest which might influence the learners' attitude towards online learning, specifically (i) the technological challenges and (ii) pedagogical challenges. Each of them will be analysed in turn in the following sections.

\subsection{Computer Infrastructure, Use and Internet Access}

Data from the study shows that the majority of learners (63\%) had access to the internet during the Covid-19 lockdown, whereas 38\% encountered difficulties (Table. 2). This corresponds with the number of learners (29\%) coming from rural areas which are still having problems related to maintaining an internet connection (OECD, 2020). However, the internet does not guarantee the quality of the connectivity which can vary widely depending on the area where the learners live (rural or urban) or the type of connectivity they use (ADSL, telephone connection, public facilities etc).

Regarding the question on what type of electronic devices they used to attend the online classes, half of the learners (55\%) stated that they used their smartphone, whereas $43 \%$ of them used a computer. Only $2 \%$ reported possessing neither a smartphone or computer.

Table 2: Internet accessibility and digital devices

\begin{tabular}{|c|c|c|c|}
\hline Q 1 & Easy & Difficult & $\begin{array}{c}\text { Neither easy nor } \\
\text { difficult }\end{array}$ \\
\hline Frequency & 105 & 48 & 15 \\
\hline Percentage & 62.6 & 28.57 & 8.92 \\
\hline Q 2 & Computer & Smartphone & I don't have any \\
\hline Frequency & 72 & 92 & 4 \\
\hline Percentage & 42.83 & 54.79 & 2.38 \\
\hline Q1. Is the internet easily accessible in your home and region? \\
\hline Q2. Did you use a computer or your smartphone to attend the online courses? \\
\hline
\end{tabular}

The analysis results in Table 3 show that the learners' level of confidence regarding the use of computers and the internet is very satisfactory. Based on the Likert scale question, $54.4 \%$ of the students were confident or extremely confident with their computer skills, whereas $10.7 \%$ them did not share the same opinion. This finding creates the premise for a positive expectation since computer skills are positively correlated with the learners' satisfaction with online learning and their learning success (Sanders et al., 2001). 
Table 3: Learners' computer literacy

\begin{tabular}{|c|c|c|c|c|c|}
\hline Q 3 & $\begin{array}{c}\text { Extremely } \\
\text { confident }\end{array}$ & Confident & $\begin{array}{c}\text { Somewha } \\
\mathbf{t} \\
\text { confident }\end{array}$ & $\begin{array}{c}\text { Not so } \\
\text { confident }\end{array}$ & $\begin{array}{c}\text { Not at all } \\
\text { confident }\end{array}$ \\
\hline Frequency & 22 & 71 & 57 & 16 & 2 \\
\hline Percentage & 13.1 & 42.3 & 33.9 & 9.5 & 1.2 \\
\hline Q 4 & $\begin{array}{c}\text { Elementary } \\
\text { school }\end{array}$ & High school & $\begin{array}{c}\text { Universit } \\
\mathbf{y}\end{array}$ & $\begin{array}{c}\text { Private } \\
\text { course }\end{array}$ & None \\
\hline Frequency & 20 & 75 & 32 & 7 & 34 \\
\hline Percentage & 11.9 & 44.6 & 19.0 & 4.3 & 20.2 \\
\hline Q3. What is your level of knowledge regarding using computers and the internet? \\
\hline Q4. Have you taken a computer course at any level of your education? \\
\hline
\end{tabular}

The high number of learners feeling confident with their computer literacy is related to the efforts made by the Albanian Ministry of Education which has considered the digitalization of schools and digital competencies to be one of its priorities (OECD, 2020). The participants in the study admitted that they had been introduced to computer skills in elementary school. They had taken computer courses at different levels of their education as part of the school curriculum (mostly in high school $-45 \%$ ) or taken it as a private course $(20 \%)$. However, UNESCO (2017) underlined a number of gaps in the ICT course content and ICT infrastructure in Albanian schools which requires immediate attention. A significant evidence that supports the conclusions from this report is the number of learners $(20.2 \%)$ in the study who said that they had never attended a computer course. This happens at schools which do not have the adequate ICT infrastructure.

\subsection{E-learning - prior experiences}

In order to determine the extent to which the learners' prior experience with online programs had contributed to their satisfaction with the online courses taken during lockdown, the students were asked if they had ever enrolled on any online courses before March 2020 (Table 4). A large number of the participants $(73.8 \%)$ confirmed that they had never taken online courses before, which means that the majority of them were totally unfamiliar with any type of e-learning environment. Only a few of them had some prior experience $(26.2 \%)$ with online courses, but we do not know for what purpose and for how long.

Table 4: Learners' prior experience with virtual classes

\begin{tabular}{|l|l|l|l|l|l|}
\hline Q 5 & 0 & 1 & 2 & 3 & 4 or more \\
\hline Frequency & 124 & 17 & 14 & 8 & 5 \\
\hline Percentage & 73.8 & 10.1 & 8.3 & 4.8 & 3.0 \\
\hline Q5. Have you taken online courses before March 2020? If yes, how many? \\
\hline
\end{tabular}

On the other hand, half of the learners (56\%) reported having been introduced to some theoretical information on distance learning, whereas $44 \%$ of them knew nothing about virtual classrooms (Table 5). We believe that the former were students from the Faculty of Education where online learning is introduced in courses whose focus is on teaching methodologies and the use of new technology 
in education. However, the learners' reaction to the next question suggests that in spite of having some idea of what distance learning is, it has not been enough to make them feel comfortable with online platforms and tools.

Table 5: Learners' theoretical knowledge of virtual classes

\begin{tabular}{|l|l|l|}
\hline Q6 & Frequency & Percentage \\
\hline YES & 94 & 56 \\
\hline NO & 74 & 44 \\
\hline Total & 168 & 100 \\
\hline Q6. Is e-learning part of your curriculum? \\
\hline
\end{tabular}

From the students' perspective, theoretical knowledge on distance learning was not enough to support them in the online environment. When asked if they needed some training before taking the online courses, $66 \%$ of the students agreed that they needed some training and only a small number of learners $(13.7 \%)$ felt confident using the online platform (Table 6). This number might represent the learners who already have some prior experience with online learning.

Table 6: Learners' need for training

\begin{tabular}{|c|c|c|c|c|c|}
\hline Q 7 & $\begin{array}{c}\text { Strongly } \\
\text { Agree }\end{array}$ & Agree & Neutral & Disagree & $\begin{array}{c}\text { Strongly } \\
\text { Disagree }\end{array}$ \\
\hline Frequency & 28 & 82 & 35 & 19 & 4 \\
\hline Percentage & 16.7 & 48.8 & 20.8 & 11.3 & 2.4 \\
\hline \multicolumn{4}{|l}{ Q7. Do you think you need some training before taking online courses? } \\
\hline
\end{tabular}

Without an initial orientation on how to use online resources, the quality of the Albanian learners' online experience decreased. The necessity of providing students with some technical training on the online learning platforms since the start of online programs is highlighted in many studies (Jones \& Gallen, 2016; Pan \& Sullivan, 2005). In addition, moving from one online platform to another in a short space of time is not a good strategy since it might have a negative impact on both the students and instructors. The learners in this study started their first online experience with the Zoom platform but during the spring 2020 semester, the teaching/learning shifted to the Moodle platform.

\subsection{Learners' perception of e-learning}

The learners were given 6 options for the advantages and limitations of synchronous learning (Tables 7 and 8). The most frequent advantages of elearning chosen by the learners were the lower cost of online programs (44\%), not having to travel every day to campus $(40 \%)$ and the feeling of being more comfortable at home (31\%). About the same number of learners $(28 \%$ and $27 \%)$ admitted that they liked the use of new technology in education and that synchronous e-learning had helped them improve their computer and internet skills. Only a small number of learners (24\%) enjoyed the opportunity to study at their own pace. 
Table 7: Learners' perception of the advantages of synchronous learning

\begin{tabular}{|l|l|l|}
\hline Q 8 & Frequency & Percentage \\
\hline I don't have to go to school every day & 68 & 40.29 \\
\hline I improved my computer skills & 47 & 28.35 \\
\hline It is less expensive & 75 & 44.77 \\
\hline I have control over my study pace & 40 & 23.88 \\
\hline I am more comfortable at home & 53 & 31.34 \\
\hline I like technology in teaching and learning & 46 & 27.61 \\
\hline $\begin{array}{l}\text { Q 8. What do you think are some of the advantages of taking online courses? More } \\
\text { than one answer is possible. }\end{array}$
\end{tabular}

The results from Table 8 show that $41 \%$ of the learners lacked motivation which is a significant predictor of the students' attitude toward online learning. Another reason for the students' low positive attitude toward synchronous learning is poor access to online platforms (42\%) that frequently manifested itself in signal and sound loss. A lack of immediate feedback $(37.3 \%)$ and a feeling of isolation (29\%) were among the factors that intervened in the students' satisfaction with online learning. Finally, the Albanian students reported problems with time management $(25 \%)$ and noises from the environment (25\%).

Table 8: Learners' perception of the limitations of synchronous learning

\begin{tabular}{|l|l|l|}
\hline Q 9 & Frequency & Percentage \\
\hline Lack of motivation & 69 & 41.04 \\
\hline Poor Internet connection & 71 & 42.13 \\
\hline No immediate feedback & 63 & 37.31 \\
\hline Problems with time management & 43 & 25.37 \\
\hline Feeling of isolation & 49 & 29.10 \\
\hline Noises and other distractions & 43 & 25.37 \\
\hline $\begin{array}{l}\text { Q9. What do you think are some of the disadvantages of online courses? More than } \\
\text { one answer is possible. }\end{array}$ \\
\hline
\end{tabular}

Two third of the learners (75\%) admitted that face to face interactions were better than online interactions (Table 9). One reason why interactions fail in online learning is related to the learners and instructors' knowledge and skills related to coping with the online platforms (Coman et al., 2020). Many of them found themselves unprepared and with little to no knowledge of how to use the synchronous tools for effective communication and learning. In the face-to-face format, the instructor and learners are physically in the classroom and the amount of time they spend together is considerable enough to reduce the feeling of isolation. Another reason is the lack of instructor flexibility to adjust their teaching style to the online environment (Bower, 2011).

Table 9: Learners' perception of instructor-student and student-student interactions

\begin{tabular}{|l|l|l|}
\hline Q 10 & Frequency & Percentage \\
\hline Internet & 42 & 25 \\
\hline Face to face & 126 & 75 \\
\hline Total & 168 & 100 \\
\hline $\begin{array}{l}\text { Q10. Is it easier for you to interact with your instructors and peers via the } \\
\text { internet or through face to face interactions? }\end{array}$ \\
\hline
\end{tabular}


Finally, data from the survey indicates that overall, the Albanian students' attitude towards online learning was not very satisfactory. More than half of the learners $(54.7 \%)$ were not optimistic about taking online classes in the future (Table 10). Considering the challenges that they faced during 2020 online courses, the Albanian learners (61\%) preferred that the teaching/learning process take place in a physical environment, that is face-to-face rather than online. The second choice was blended learning $(29 \%)$ which is a combination of online and offline courses, while only $10.1 \%$ would prefer online learning.

Table 10: Learners' preference for face-to-face format

\begin{tabular}{|c|c|c|c|c|c|}
\hline Q 11 & $\begin{array}{c}\text { Strongly } \\
\text { Agree }\end{array}$ & Agree & Neutral & Disagree & $\begin{array}{c}\text { Strongly } \\
\text { Disagree }\end{array}$ \\
\hline Frequency & 10 & 17 & 49 & 54 & 38 \\
\hline $\begin{array}{c}\text { Percentag } \\
\text { e }\end{array}$ & 6.0 & 10.1 & 29.2 & 32.1 & 22.6 \\
\hline Q 12 & Face to face Learning & \multicolumn{2}{|c|}{ Online Learning } & Blended \\
\hline Frequency & 102 & \multicolumn{2}{|c|}{17} & 49 \\
\hline $\begin{array}{c}\text { Percentag } \\
\text { e }\end{array}$ & 60.7 & \multicolumn{2}{|l|}{10.1} & 29.2 \\
\hline & \multicolumn{5}{|l|}{} \\
\hline
\end{tabular}

\section{Discussion and conclusion}

This study aimed to investigate the Albanian learners' attitudes towards elearning in the context of the challenges imposed by the Covid-19 pandemic on the Albanian higher education system. The transition from face-to-face learning to the e-learning format was not easy. The students experienced difficulties during the transition to all courses being online and the findings from the study relate the students' dissatisfaction towards the online learning with technological and pedagogical challenges.

Access to the internet at a fast speed and the availability of ICT devices seems to be a basic prerequisite for e-learning (Karakaya et al., 2020). However, the study showed that not all learners have a fast internet connection or a powerful electronic device. The results indicate that a considerable number of learners had problems with their internet connection and may not own a computer (UNESCO, 2017). Some European countries have addressed this problem by taking the initiative to assist families who cannot afford to have one (Ferri et al., 2020). Unfortunately, the Albanian government has failed to provide free computers to disadvantaged learners but it has been able to reduce the cost of a decent internet connection for a short period of time.

In addition, studies have shown a positive correlation between the students' level of computer literacy and their experience with online tools. Not surprisingly, the Albanian learners reported good computer skills as a basic computer course is part of their education curriculum. However, the ICT course in pre-university 
education covers a wide range of topics related to Microsoft programs and navigation on the internet which, as the results showed, were not enough to help the students cope successfully with online e-learning platforms and their tools. Although the tools offered by the e-learning platforms are easy to use and intuitive, half of the Albanian learners (66\%) agreed that they needed some training on how to use them effectively. One reason for their inability to use online platforms efficiently is the fact that half of them used smartphones which have many technological limitations compared to computers. This finding is consistent with the results reported in Xhelili et al.'s study (2021) where Albanian students studying technology-based programs were more satisfied with online courses than the students studying life sciences.

The most interesting finding from this study is the learners' attitude towards synchronous e-learning. The Albanian learners showed a greater interest in traditional face-to-face classes rather than synchronous teaching. This finding is in line with the results from another study (Xhelili et al., 2021) where the Albanian students also showed a great preference for face-to-face learning. The two most favourite formats chosen by the learners as future trends in teaching and learning in higher education in Albania were face-to-face and blended models. The learners' preference for blended learning is also consistent with the results reported in other studies (Kumari \& Jayasinghe, 2021; Bordoloi et al., 2021). We believe that they favour blended learning over synchronous e-learning due to the fact that it preserves select face-to-face features.

Unlike the results reported in other studies (Fidalgo et al., 2020; Peck et al., 2018), the most highlighted benefit of online learning for Albanian learners was its cost. Albania is still among the poorest countries in Europe (European Commission, 2019) which explains why Albanian learners are so sensitive towards the study tuition fee. The economic issues might partially explain the next choice. The learners were satisfied with the online courses since they did not have to go to school every day which meant a reduction in their daily expenses including bus tickets, food etc. In addition, due to the assertion that they feel more comfortable at home than at university, this also raises the question of the university infrastructure and how it might not be that satisfactory. The least chosen options were control over their study pace and time management. The Albanian learners failed to appreciate the learning independence offered by synchronous learning which requires the instructors to adapt face-to-face instructions to online learning features (Coman et al., 2020).

Regarding the disadvantages of synchronous learning, a poor internet connection and low motivation were highlighted by the students as the main reasons for their dissatisfaction. The loss of human interaction between the teachers and students and the lack of immediate feedback has also led the students toward feelings of isolation. It seems as though there is no tool in online learning to substitute for face-to-face instructor-student and student-student interactions.

The Albanian learners were used to face-to-face courses where they meet in person with their instructors and peers. Moving from traditional classes to online 
communication without any preparation on how to compensate for the lack of physical contact might have been hard for them. This was made worse by the quarantine (March-June 2020) when they were deprived not only of campus life but from any social contact other than their families. This leads us to believe that perhaps the instructors failed to use the virtual classroom features which are expected instead to promote collaboration, community and interaction (Cook et al., 2011; Martin \& Parker, 2014). However, this is an issue to be addressed in the future not only by researchers but also by faculties and instructors. The feeling of isolation and the low level of interactions reported by the learners indicate a need for an immediate change in online teaching pedagogy.

There are several things we would like to suggest in order to overcome the technological and pedagogical challenges related to e-learning in Albania.

The technological challenges reported in this study were related to a poor internet connection, a lack of digital devices and computer literacy. The first two issues can be addressed by government policies, first to secure full internet coverage and the adoption of 5G throughout the country and second, to improve people's financial situation while reducing the price of electronic devices. The third issue concerns the faculties regarding curriculum development so that they provide courses which support the students with the proper computer literacy and training on how to use e-learning platforms and their tools.

Pedagogical challenges are related to the use of an adequate online platform, the teaching materials and the teaching style (Ferri et al., 2020). It is crucial that online platforms have all of the necessary features allowing instructors to use a wide range of digital resources in order to maintain the learners' interest and their motivation. Furthermore, it is necessary that the platforms are chosen carefully and not changed over a short period of time. In addition, the faculties should train their staff not only on how to use online platforms and their tools but also on how to construct a meaningful and well-planned online syllabus. Instructors need to apply different forms of online communication with their students in order to create a friendly online environment that can reduce the feeling of isolation. They should respond to the students more frequently by giving instant feedback which can increase their intrinsic motivation and participation in the e-classes.

Finally, the Albanian Ministry of Education should accredit online programs where all of the demands for qualitative online teaching are met so then this trend continues while improving itself. However, blended learning is for the moment the best option offered by Albanian IHEs as an effective learning format in the future since it satisfies not only the growing demand for e-learning but also the need by learners and instructors to maintain certain aspects of the face-to-face approach.

\section{Limitations of the study}

This study is an attempt to shed light on the Albanian learners' attitude towards synchronous learning during the Covid-19 pandemic. It provides some information on the challenges faced by Albanian learners during the spring 2020 
semester which need to be addressed in order to improve their online learning experience in the future. However, the present study has its limitations. First, the participants in this study were from two Albanian universities in the field of humanities and sciences. In total, there were 168 students which makes this sample not representative of the entire population. The findings from this study cannot be generalised to the overall population at large. Second, this study focused on the learners' perceptions of online learning but there was no data from the actual virtual classrooms which would help us to better understand the learners' perception of the online course design. Finally, longitudinal studies are needed to understand the progress made in online pedagogy and the effect of the institutional and government policies on online learning.

\section{References}

Abel R. (2005). Implementing best practices in e-learning. Educause Quarterly, 28(3), 75-77.

Alammary, A., Sheard, J., \& Carbone, A. (2014). Blended learning in higher education: Three different design approaches. Australasian Journal of Educational Technology, 30(4), 440-454. https:// doi.org/10.14742/ajet.693

Allen, I. E., \& Seaman, J. (2013). Changing course: Ten years of tracking online education in the United States. Babson Park, MA: Babson Survey Research Group and Quahog Research Group.

Aytac, T. (2021). The Problems Faced by Teachers in Turkey During the COVID-19 Pandemic and Their Opinions. International Journal of Progressive Education, 17(1), 404-420.

Betts, K. (1998). An institutional overview: Factors influencing faculty participation in distance education in postsecondary education in the United States: An institutional study. Online Journal of Distance Learning Administration, 1(3). https://www.westga.edu/ distance/betts13.html

Bhuasiri, W., Xaymoungkhoun, O., Zo, H., Rho, J. J., \& Ciganek, A. P. (2012). Critical success factors for e-learning in developing countries: A comparative analysis between ICT experts and faculty. Computer and Education, 58(2), 843855. https://doi.org/10.1016/j.compedu.2011.10.010

Bordoloi, R., Das, P., \& Das, K. (2021). Perception towards online/blended learning at the time of Covid-19 pandemic: an academic analytics in the Indian context. Asian Association of Open Universities Journal, 16(1), 4160. https://doi.org/10.1108/aaouj-09-2020-0079

Bower, M. (2011). Synchronous collaboration competencies in web-conferencing environments - their impact on the learning process. Distance Education, 32(1), 6383. https://doi.org/10.1080/01587919.2011.565502

Brereton, P. (2021). Emergency remote training: guiding and supporting teachers in preparation for emergency remote teaching. Language Research Bulletin, 35.

Cheawjindakarn, B., Suwannatthachote, P., \& Theeraroungchaisri, A. (2012). Critical success factors for online distance learning in higher education: a review of the literature. Creative Education, 3(8), 61-66. https:// doi.org/10.4236/ce.2012.38b014

Chen, E., Kaczmarek, K., \& Ohyama, H. (2020). Student perception of distance learning strategies during COVID 19. Journal of Dental Education, 1-2. https://doi.org/10.1002/jdd.12339

Cojocariu, V. M., Lazar, I., Nedeff, V., \& Lazar, G. (2014). SWOT analysis of e-learning educational services from the perspective of their beneficiaries. Procedia Social and Behavioral Sciences, 116, 1999-2003. https://doi.org/10.1016/j.sbspro.2014.01.510 
Coman, C., Tiru, L. G., Schitz, L. M., Stanciu, C., \& Bularca, M. C. (2020). Online Teaching and Learning in Higher Education during the Coronavirus Pandemic: Students' Perspective. Sustainability, 12(24), 10367. https://doi.org/10.3390/su122410367

Cook, M., Annetta, L. A., Dickerson, D. L., \& Minogue, J. (2011). In-service teachers' perceptions of e-learning environments. Quarterly Review of Distance Education, 12(2), 73-79.

Ferri, F., Grifoni P., \& Guzzo, T. (2020). Online Learning and Emergency Remote Teaching: Opportunities and Challenges in Emergency Situations. Societies, 10(4), 86. https://doi.org/10.3390/soc10040086

Fidalgo, P., Thormann, J., Kulyk, O., \& Lencastre, J. A. (2020). Students' perceptions on distance education: A multinational study. International Journal of Educational Technology in Higher Education, 17(1). https://doi.org/10.1186/s41239-020-001942

Gillis, A., \& Krull, L. M. (2020). COVID-19 Remote Learning Transition in Spring 2020: Class Structures, Student Perceptions, and Inequality in College Courses. Teaching Sociology, 48(4), 283-299. https:/ / doi.org/10.1177/0092055X20954263

Hrastinski, S. (2008). Asynchronous and synchronous e-learning. Educause Quarterly, $31(4), 51-55$.

Jan, A. (2020). A phenomenological study of synchronous teaching during COVID-19: A case of an international school in Malaysia. Social Sciences and Humanities Open, 2(1), 100084. https://doi.org/10.1016/j.ssaho.2020.100084

Jones, M. H., \& Gallen, A. M. (2016). Peer observation, feedback and reflection for development of practice in synchronous online teaching. Innovations in Education and Teaching International, 53(6), 616-626. https://doi.org/10.1080/14703297.2015.1025808

Jorgoni, E. (2019). ESPN Thematic Report on In-work poverty - Albania, European Social Policy Network (ESPN). Brussels: European Commission.

Karakaya, F., Arik, S., Çimen, O., \& Yilmaz, M. (2020). Investigation of the Views of Biology Teachers on Distance Education during the COVID-19 Pandemic. Journal of Education in Science, Environment and Health, 6(4), 246-258. https://doi.org/10.21891/jeseh.792984

Kentnor, E. (2015). Distance education and the evolution of online learning in the United States. Curriculum and Teaching Dialogue, 17(1-2), 21-34.

Kumari, K.W.S.N., \& Jayasinghe, G.J.M.S.R. (2021). Undergraduate Students' Readiness for Blended Learning During COVID-19 Pandemic in Sri Lanka. SSRN. Advance online publication. http://dx.doi.org/10.2139/ssrn.3831219

Kurki, T., Masdeu, F., Gardinier, M., Mkrtchyan, A., Baumann, R., Loi, M., Søby, M., \& Henderson, K. (2017). Albania Education Policy Review: Issues and Recommendations (extended report). Paris, France: UNESCO.

Lee, Y. C. (2008). The role of perceived resources in online learning adoption. Computer and Education, 50(4), 1423-1438. https://doi.org/10.1016/j.compedu.2007.01.001

Li, L. Y., \& Lee, L. Y. (2016). Computer Literacy and Online Learning Attitude toward GSOE Students in Distance Education Programs. Higher education Studies, 6(3), 147. https:// doi.org/10.5539/hes.v6n3p147

Martin, F., \& Parker, M. A. (2014). Use of Synchronous Virtual Classrooms: Why, Who and How? Merlot Journal of E-learning and Teaching, 10(2), 192-210.

Muthuprasad, T., Aiswarya, S., Aditya, K. S., \& Jha, G. K. (2021). Students' perception and preference for online education in India during COVID-19 pandemic. Social

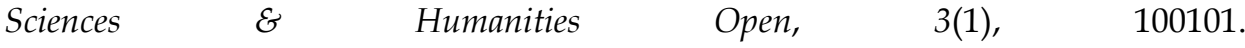
https://doi.org/10.1016/j.ssaho.2020.100101 
Pan, C. C., \& Sullivan, M. (2005). Promoting synchronous interaction in an eLearning environment. Technical Horizons in Education Journal, 33(2), 27-30.

Park, Y. J., \& Bonk, C. (2007). Synchronous Learning Experiences: Distance and Residential Learners' Perspectives in a Blended Graduate Course. Journal of Interactive Online Learning, 6(3), 245-264.

Peck, L., Stefaniak, J. E., \& Shah, S. J. (2018). The correlation of self-regulation and motivation with retention and attrition in distance education. Quarterly Review of Distance Education, 19(3), 1-15.

Pellegrini, M., \& Maltinti, C. (2020). 'School Never Stops': Measures and Experience in Italian Schools during the COVID-19 Lockdown. Best Evidence Chinese Education, 5(2), 649-663. https:// doi.org/10.15354/bece.20.or021

Phelps, A., \& Vlachopoulos, D. (2020). Successful transition to synchronous learning environments in distance education: A research on entry-level synchronous facilitator competencies. Education and Information Technologies 25(3), 1511-1527. https://doi.org/10.1007/s10639-019-09989-x

Pokhrel, S., \& Chhetri, R. (2021). A Literature Review on impact of COVID 19 Pandemic on Teaching and Learning. Higher Education for the Future, 8(1), 133-141. https:// doi.org/10.1177/2347631120983481

Porter, W. W., Graham, C. R., Spring, K. A., \& Wech, K. R. (2014). Blended learning in higher education; Institutional adoption and implementation. Computer and Education, 75, 185-195. https://doi.org/10.1016/j.compedu.2014.02.011

Raikou, N., Kaltsidis, C., Kedraka, K., \& Karalis, T. (2020). Teaching in Times of COVID-19 Pandemic in Two Peripheral Greek Universities: Lessons Learned from Students' Experiences and Opinions. Research Journal of Education, 6(8), 135-143. https://doi.org/10.32861/rje.68.135.143

Ramola, R. C. (2021). Challenges and Opportunities for Higher Education amid COVID19 Pandemic. International Journal of Computer Engineering in Research Trends, 8(2), 29-32. https:// doi.org/10.13140/RG.2.2.30144.76803

Sanders, D. W., Alison, I., \& Morrison, S. (2001). Student attitudes toward Web-enhanced instruction in an introductory biology course. Journal of Research on Computing in Education, 33(3), 251-262. http://dx.doi.org/10.1080/08886504.2001.10782313

Seifert, T. (2019). Improving Involvement Through Interaction in Synchronous Teaching/Learning in Higher Education. In J. Yoon, \& P. Semingson (Eds.), Educational Technology and Resources for Synchronous Learning in Higher Education (pp. 229-254). IGI Global. http:/ / doi:10.4018/978-1-5225-7567-2.ch012

Shukri, A., Nordin, L., Salleh, F. I. M., Raidzwan, S. N. M., \& Ahmad, R. (2020). UniKL students' perception on synchronous learning using ICT as learning tools to learn $\begin{array}{lllll}\text { English. Journal of Critical Reviews, 7(8), 793-796. } & \end{array}$ https://doi.org/10.31838/jcr.07.08.170

Toquero, C. M. (2020). Challenges and Opportunities for Higher Education amid the COVID-19 Pandemic: The Philippine Context. Pedagogical Research, 5(4), em0063. https://doi.org/10.29333/pr/7947

Valverde-Berrocoso, J., Garrido-Arroyo, M. del C., Burgos-Videla, C., \& Morales-Cevallos, M. B. (2020). Trends in education research about e-Learning a systematic literature $\begin{array}{llll}\text { review (2009-2018). } & \text { Sustainability, }\end{array}$ https://doi.org/10.3390/su12125153

Xhelili, P., Ibrahimi, E., Rruci, E., \& Sheme, K. (2021). Adaptation and perception of online learning during COVID-19 pandemic by Albanian university students. International Journal on Studies in Education, 3(2), 103-111. https:// doi.org/10.46328/ijonse.49 
Yang, X., Li, D., Liu, X., \& Tan, J. (2020). Learner behaviors in synchronous online prosthodontic education during the 2020 COVID 19 pandemic. The Journal of prosthetic dentistry. https:/ / doi.org/10.1016/j.prosdent.2020.08.004

Yilmaz, A. B. (2019). Distance and face-to-face students' perceptions towards distance education: A comparative metaphorical study. Turkish Online Journal of Distance Education-TOJDE, 20(1), 191-207. https://doi.org/10.17718/tojde.522705

Yuzer, V. T., Aydin, B., \& Gonen, S. I. K. (2009). Learners' Perceptions Toward E-learning: An Application for a Synchronous E-Class. I-manager's Journal of Educational Technology, 6(2), 30-40. https://doi.org/10.26634/jet.6.2.799

Zabadi, A., \& Al-Alawai, A. H. (2016). University Learners' Attitudes towards E-learning: University of Business and Technology (UBT)-Saudi Arabia-Jeddah: A Case Study. International Journal of Business and Management, 11(6), 286-295. https://doi.org/10.5539/ijbm.v11n6p286

Zhou, T., Huang, S., Cheng, J., \& Xiao, Y. (2020). The distance teaching practice of combined mode of massive open online course micro-video for interns in the emergency department during the COVID-19 epidemic period. Telemedicine and $e-$ Health, 26(5), 584-588. https://doi.org/10.1089/tmj.2020.0079

\section{APPENDIX A: (Online Survey Questions)}

You are invited to participate in a research study that helps to evaluate Albanian students' attitude toward synchronous learning during the period March- June, 2020. This survey takes less than 10 minutes to complete. The survey is anonymous. Click on the link below if you provide your consent.

\section{Your Gender}

Female

Male

2. Choose the program level you are actually attending.

Bachelor-first year

Bachelor-second year

Bachelor-third year

Master-first year

Master-second year

3. Where do you live?

Urban area

Rural area

4. How old are you?

18-19

20-21

- 22-23

24-27

Other (please specify) 
5. Is internet easily accessible at your home and region?

Easy

Difficult

Neither easy nor difficult

6. Did you use the computer or your smartphone to attend online courses?

Computer

Smartphone

I don't have the necessary device to access internet

7. What is your level of knowledge in regard to using computer and internet?

Extremely confident

Very confident

Somewhat confident

Not so confident

Not at all confident

8. Have you taken computer courses at any level of your education?

Elementary school

High school

University

Private course

None

9. Have you taken online courses before March 2020? If yes, how many?

0

1

○ 2

3

4

more than 4

9. Is online learning part of your curriculum?

Y Yes

No

10. Do you think you needed preparation before taking online courses?

Strongly agree

Agree

Neither agree nor disagree

Disagree

Strongly disagree 
11. What do you think are some of the advantages of taking online courses? More than one answer is possible.

I don't have to go to school every day

$\ulcorner$ I improved my computer and internet skills

$\lceil$ It is less expensive

$\ulcorner$ I have control over my study time

$\lceil$ I am more comfortable at home

I like the use of technology in teaching and learning

12. What do you think are some of the disadvantages of online courses? More than one answer is possible.

$\lceil$ I lack of motivation

I had problems with internet connection

$\ulcorner$ No immediate feedback from instructor or peers

$\ulcorner$ I had problems with time management

$\Gamma$ I felt isolated

$\Gamma$ Noises and other distractions

13. Is it easier for you to interact with instructors and peers via internet or face to face interaction?

Internet

Face to face interaction

14. Would you like to continue having online courses in the future?

Strongly agree

Agree

Neither agree nor disagree

Disagree

Strongly disagree

15. Which type of learning do you prefer?

Face to face courses

Online courses

Blended learning (a mix of learning online and face to face) 